\title{
KEABSAHAN AKTA NOTA RIIL DITINJAU DARI UNDANG-UNDANG NOMOR 2 TAHUN 2014 TENTANG PERUBAHAN ATAS UNDANG-UNDANG NOMOR 30 TAHUN 2004 TENTANG JABATAN NOTARIS
}

\author{
Oleh : Bambang Eko Muljono, SH, S.pN, M.Hum, MMA
}

\begin{abstract}
Abstrak
Negara Republik Indonesia merupakan suatu negara hukum dimana kekuasaan tunduk pada hukum . Hukum mengatur segala hubungan antar individu atau perorangan dan individu dengan kelompok atau masyarakat maupun individu dengan pemerintah. Prinsip negara hukum menjamin kepastian, ketertiban,dan perlindungan hukum yang berintikan kebenaran dan keadilan. Dalam mewujudkan hal tersebut memerlukan adanya alat bukti. Salah satu alat bukti tersebut dapat berupa akta otentik .

Kekuatan pembuktian akta notaris dalam perkara perdata dan pidana, merupakan alat bukti yang sah menurut undang-undang dan bernilai sempurna. Nilai kesempurnaanya tidak dapat berdiri sendiri, tetapi memerlukan dukungan alat bukti lain berupa akta notaris. Namun notaris tidak menjamin bahwa apa yang dinyatakan oleh penghadap tersebut adalah benar atau suatu kebenaran. Notaris yang melakukan pelanggaran dalam menjalankan tugas jabatannya dapat diterapkan beberapa sanksi diantaranya, sanksi administratif, sanksi perdata, sanksi pidana dan sanksi kode etik. Penerapan sanksi tersebut tidak dapat dilakukan bersama-sama ,oleh karena sanksi-sanksi tersebut berdiri sendiri yang dapat dijatuhkan oleh intansi yang diberikan kewenangan untuk menjatuhkan sanksi tersebut.
\end{abstract}

Kata Kunci :Akta Nota Riil, Jabatan Notaris.

\section{PENDAHULUAN}

Negara Republik Indonesia merupakan suatu negara hukum dimana kekuasaan tunduk pada hukum . Hukum mengatur segala hubungan antar individu atau perorangan dan individu dengan kelompok atau masyarakat maupun individu dengan pemerintah. Prinsip negara hukum menjamin kepastian, ketertiban,dan perlindungan hukum yang berintikan kebenaran dan keadilan. Dalam mewujudkan hal tersebut memerlukan adanya alat bukti. Salah satu alat bukti tersebut dapat berupa akta otentik.

Kekuatan pembuktian akta notaris dalam perkara perdata dan pidana, merupakan alat bukti yang sah menurut undang-undang dan bernilai sempurna. Nilai kesempurnaanya tidak dapat berdiri sendiri, tetapi memerlukan dukungan alat bukti lain berupa akta notaris . Namun notaris tidak menjamin bahwa apa yang dinyatakan oleh penghadap tersebut adalah benar atau suatu kebenaran. Notaris yang melakukan pelanggaran dalam menjalankan tugas jabatannya dapat diterapkan beberapa sanksi diantaranya, sanksi administratif, sanksi perdata, sanksi pidana dan sanksi kode etik . Penerapan sanksi tersebut tidak dapat dilakukan bersama-sama ,oleh karena sanksisanksi tersebut berdiri sendiri yang dapat dijatuhkan oleh intansi yang diberikan kewenangan untuk menjatuhkan sanksi tersebut.

Kehidupan manusia sebagai subyek hukum yang hidup berinteraksi antara individu satu dengan individu lain, individu dengan kelompok individu, kelompok yang satu dengan kelompok yang lain menjadi satu konsekuensi bahwasanya hidup manusia pada hakekatnya adalah berinteraksi. Bahasa interaksi adalah merupakan bahasa komunikasi saja diantara individu dan kelompok, akan tetapi di dalam bahasa hukum hakekat hidup berinteraksi manusia itu merupakan hubungan hukum. Hubungan hukum inilah yang merupakan hubungan interaksi antara individu dan kelompok yang paling rasional, disebabkan hubungan hukum memiliki porsi dan alat ukur yang jelas di dalam sebuah hubungan.

Hubungan antara manusia yang satu dengan manusia yang lainnya selalu terwujud dalam pergaulan sehari-hari. Hal ini disebabkan adanya tujuan dan kepentingan yang sangat beraneka ragam. Dalam hal adanya tujuan dan kepentingan yang ingin dicapai maka untuk mewujudkan kebutuhan para pihak tersebut, terlebih dahulu harus dipertemukan kehendak yang mereka inginkan, yang harus dituangkan dalam sebuah perjanjian yang dibuat oleh kedua belah pihak atau lebih, untuk menjamin kepastian terlaksananya perbuatan hukum tersebut maka perjanjian yang dibuat oleh para pihak atau lebih harus sesuai dengan syarat syahnya sebuah perjanjian yang tertuang di dalam pasal ada di dalam KUH Perdata Pasal 1320 BW menentukan empat syarat syahnya suatu perjanjian yaitu :

"Sepakat mereka yang mengikatkan diri, Kecakapan untuk membuat perjanjian ,Suatu hal tertentu , Suatu sebab yang diperbolehkan “

Apabila syarat syah di dalam perjanjian itu sudah di penuhi maka sebuah perjanjian dapat dijadikan alat bukti yang kuat apabila kedua belah pihak atau lebih ada yang mengalami kerugian 
yang disebabkan karena ada yang melakukan ingkar janji atau wanprestasi di dalam pasal-pasal yang ada di dalam sebuah perjanjian yang dibuatnya, perbuatan hukum kedua belah pihak atau lebih yang dituangkan dalam perjanjian yang sudah memenuhi syarat syahnya suatu perjanjian yang bisa dijadikan sebagai alat bukti surat yang digolongkan sebagai akta dibawah tangan, dan apabila sebuah perjanjian dibuat oleh para pihak atau lebih itu dihadapan pejabat umum atau disebut Notaris, tergolong sebagai akta otentik yang dapat dijadikan sebagai alat bukti yang sempurna, Untuk menjamin kepastian terlaksananya perbuatan hukum dengan baik diperlukan sebagai sarana alat bukti yang sempurna .

Akan tetapi Jabatan Notaris merupakan salah satu pejabat umum yang selain menjalankan kewenangan jabatanya dia juga dibatasi tanggung jawab jabatanya, oleh sebuah peraturan jabatan yang ada khususnya dalam membuat akta perjanjian yang dibuat oleh para pihak atau lebih dihadapan Notaris, Undang-Undang Nomor 2 Tahun 2014 Tentang Perubahan Atas UndangUndang Nomor 30 Tahun 2004 Tentang Jabatan Notaris (UUJN) merupakan upaya dari pembentuk undang-undang untuk melakukan reformasi hukum termasuk dalam dunia kenotariatan dengan mengganti Peraturan Jabatan Notaris (PJN) yang merupakan warisan pemerintah Kolonial Belanda yang dipandang tidak lagi sesuai dengan keadaan, tidak dapat mengikuti perkembangan dan tuntutan hukum dalam masyarakat serta cita-cita Indonesia merdeka.

Akta Notariil adalah akta yang dibuat oleh atau dihadapan pejabat notaris , akta notaris merupakan suatu akta otentik, di mana akta otentik adalah akta yang diberi tanda tangan, yang memuat peristiwa yang menjadi dasar suatu hak atau perikatan, yang dibuat sejak semua dengan sengaja untuk pembuktian. Jadi untuk dapat digolongkan sebagai akta suatu surat harus ada tanda tangannya seperti yang disyaratkan dalam Pasal 1869 KUHPerdata bahwa suatu akta yang karena tidak berkuasa atau tidak cakapnya pegawai dimaksud di atas (Pasal 1868 KUHPer) atau karena suatu cacat dalam bentuknya, tidak dapat diperlakukan sebagai akta otentik namun demikian mempunyai kekuatan sebagai tulisan di bawah tangan jika ia ditandatangani oleh para pihak.

\section{Metode penelitian \\ Tipe Penelitian}

Tipe penelitian hukum yang dilakukan adalah yuridis normative (hukum normatif). Metode penelitian hukum normatif adalah suatu prosedur penelitian ilmiah untuk menemukan kebenaran berdasarkan logika keilmuan hukum dari sisi normatifnya.
Oleh karena itu penelitian hukum ini difokuskan untuk mengkaji penelitian hukum tentang kaidah-kaidah atau norma-norma dalam hukum positif yang terkait dengan keabsahan akta notariil dan akibat hukum penandatanganan akta yang dilakukan tidak dilakukan dihadapan Notaris.

\section{Pendekatan Masalah}

Pendekatan yang dilakukan dalam penelitian ini menggunakan pendekatan Perundang-Undangan (statue approach). Pendekatan melalui pengkajian peraturan Perundang-Undangan yang berhubungan dengan pokok permasalahan. Selain itu juga digunakan pendekatan analitis (analytical approach), pendekatan ini maksudnya menganalisa terhadap keabsahan akta notariil dan akibat hukum penandatanganan akta yang dilakukan tidak dilakukan dihadapan Notaris.

\section{Bahan Hukum}

Dalam penulisan skripsi ini penulis menggunakan bahan-bahan hukum yang meliputi:

1. Bahan Hukum Primer

Bahan hukum primer adalah merupakan bahan hukum yang bersifat autoritatif artinya mempunyai otoritas. Bahan hukum terdiri dari Perundang-undangan, catatan resmi atau risalah dalam pembuatan perundang-undangan dan putusan hakim. Adapun bahan hukum primer tersebut meliputi: Kitab Undang-Undang Hukum Perdata (KUH Perdata), Kitab UndangUndang Hukum Pidana (KUHP), UndangUndang Nomor : 2 tahun 2014 Tentang Perubahan Atas Undang-Undang Nomor 30 Tahun 2004 Tentang Jabatan Notaris tentang Jabatan Notaris.

2. Bahan Hukum Sekunder

Bahan hukum sekunder adalah bahan yang diperoleh dari buku teks, jurnal-jurnal, pendapat para sarjana dan kasus-kasus hukum.

\section{Prosedur Pengumpulan Bahan Hukum}

Baik bahan primer maupun bahan hukum sekunder dikumpulkan berdasarkan topik permasalahan yang telah dirumuskan dan diklasifikasi menurut sumber dan hirarkinya untuk dikaji secara komprehensif.

\section{Pengolahan dan Analisis Bahan Hukum}

Adapun bahan hukum yang diperoleh dalam penelitian ini adalah studi kepustakaan, aturan perundang-undangan yang penulis uraikan dan dihubungkan sedemikian rupa sehingga disajikan dalam penulisan yang sistematis guna menjawab perumusan masalah yang dirumuskan. Cara pengolahan bahan hukum dilakukan secara deduktif yakni menarik kesimpulan dari suatu 
permasalahan yang bersifat umum terhadap permasalahan kongkrit yang dihadapi yakni keabsahan akta notariil dan akibat hukum penandatanganan akta yang tidak dilakukan dihadapan Notaris.

\section{Akibat Hukum Terhadap Penandatanganan Akta Notariil Yang Dilakukan Oleh Notaris Tidak Di Hadapan Para Pihak.}

Dalam banyak kasus mengenai penandatanganan akta notariil salah-satu kasus yang bisa kita temui bahkan sering terjadi adalah mengenai penandatanganan minuta akta yang tidak ditandatangani di mana dalam kasus tersebut terdapat notaris yang tidak menandatangani minuta aktanya sampai notaris tersebut meninggal dunia.

Mekanisme penandatanganan akta notariil tidak hanya terbatas pada persoalan bahwa akta tersebut harus ditandatangani namun, penandatanganan akta tersebut juga harus dilakukan di hadapan notaris ataupun sebaliknya yaitu pembubuhan tanda tangan Notaris juga harus dilakukan dihadapan para pihak atau pada saat itu juga, sebagaimana telah diatur dalam UUJN Pasal 16 ayat (1) huruf $m$ yang berbunyi :

"membacakan akta di hadapan penghadap dengan dihadiri oleh paling sedikit 2 (dua) orang saksi,atau 4 (empat) orang saksi khusus untuk pembuatan Akta wasiat dibawah tangan, dan ditandatangani pada saat itu juga oleh penghadap, saksi, dan Notaris"

Yang mengatur tentang kewajiban Notaris untuk membacakan akta di hadapan penghadap dengan dihadiri oleh paling sedikit 2 (dua) orang saksi dan ditandatangani pada saat itu juga oleh penghadap, saksi, dan Notaris .

Akta sendiri adalah surat sebagai alat bukti yang diberi tanda tangan, yang memuat peristiwa yang menjadi dasar suatu hak atau perikatan, yang dibuat sejak semula dengan sengaja untuk pembuktian. Jadi, untuk dapat digolongkan dalam pengertian akta maka surat harus ditanda tangani. Keharusan untuk ditandatanganinya surat untuk dapat disebut sebagai akta berasal dari Pasal 1869 BW. Keharusan adanya tanda tangan tidak lain bertujuan untuk membedakan akta yang satu dengan akta yang lain atau dari akta yang dibuat orang lain.

Fungsi tanda tangan adalah untuk memberi ciri atau untuk mengindividualisir sebuah akta. Akta yang dibuat oleh $\mathrm{A}$ dan $\mathrm{B}$ dapat diidentifisir dari tanda tangan yang dibubuhkan pada akta-akta tersebut. Oleh karena itu nama atau tanda tangan yang ditulis dengan huruf balok tidaklah cukup, karena dari tulisan huruf balok itu tidak tampak ciri-ciri atau sifat-sifat pembuat.Ketentuan pasal 16 ayat (1) huruf $m$ tersebut adalah kewajiban notaris sebagaimana tertuang dalam Pasal 16 ayat (1) dan kata di hadapan adalah hadirnya seorang notaris secara fisik di hadapan para pihak dan saksi-saksi (penjelasan Pasal 16 ayat (1) huruf m UUJN).

Ketentuan ini dipertegas kembali dalam Pasal 44 UUJN menentukan bahwa:

“(1) Segera setelah akta dibacakan, akta tersebut ditanda tangani oleh setiap penghadap, saksi dan notaris kecuali apabila ada penghadap yang tidak dapat membubuhkan tanda tangannya dengan menyebutkan alasannya; (2) Alasan sebagaimana dimaksud pada ayat (1) dinyatakan secara tegas dalam akta; (3) Akta sebagaimana dimaksud pada Pasal 43 ayat (3) ditanda tangani oleh penghadap, notaris dan saksi dan penerjemah; (4) Pembacaan, penerjemahan atau penjelasan dan penadatanganan sebagaimana dimaksud pada ayat (1) dan ayat (3) dan Pasal 43 ayat (2), ayat (3) dan ayat (5) dinyatakan secara tegas pada akhir akta.

Sedangkan akibat hukum terhadap penandatanganan akta notariil yang dilakukan oleh Notaris tidak dihadapan para pihak telah diatur dalam Pasal 44 ayat ( 5 ) UUJN yang berbunyi :

"Pelanggaran terhadap ketentuan sebagaimana dimaksud pada ayat (1), ayat (2), ayat (3), dan ayat (4) mengakibatkan suatu Akta hanya mempunyai kekuatan pembuktian sebagai akta di bawah tangan dan dapat menjadi alasan bagi pihak yang menderita kerugian untuk menuntut penggantian biaya, ganti rugi, dan bunga kepada Notaris"

\section{Pengertian Notaris}

Pasal 1 angka (1) Undang-Undang Nomor 2 Tahun 2014 Tentang Perubahan Atas UndangUndang Nomor 30 Tahun 2004 Tentang Jabatan Notaris menjelaskan tentang pengertian Notaris :

"Notaris adalah pejabat umum yang berwenang untuk membuat akta autentik dan memiliki kewenangan lainnya sebagaimana dimaksud dalam Undang-Undang ini atau berdasarkan undang-undang lainnya."

Untuk memberikan penegasan bahwa Notaris adalah satu-satunya yang mempunyai wewenang tertentu, bukan pejabat lain, dapat dilihat dari definisi di atas bahwa:

a. Notaris adalah pejabat umum

b. Notaris merupakan satu-satunya pejabat yang berwenang untuk membuat akta otentik yang diberikan oleh Undangundang.

Sehubungan dengan wewenang yang diberikan bagi Notaris oleh Undang-undang maka selain Notaris, pejabat lainnya hanya mempunyai wewenang tertentu, artinya wewenang mereka 
tidak sampai pada pembuatan akta otentik sebagaimana telah ditugaskan oleh Undang-undang kepada Notaris. Adapun pejabat lain yang diberikan kewenangan membuat akta otentik selain Notaris salah satu contoh adalah Pegawai Kantor Catatan Sipil .

Meskipun pejabat ini hanya menjalankan fungsi sebagai Pejabat Umum akan tetapi mereka itu bukan Pejabat Umum. Mengenai otentisitas suatu akta Notaris, lebih lanjut Soegondo Notodisoerjo, menyatakan: Bahwa untuk dapat membuat akta otentik, seseorang harus mempunyai kedudukan sebagai "penjabat umum". Di Indonesia, seorang advokat meskipun ia seorang ahli dalam bidang hukum, tidak berwenang untuk membuat akta otentik, karena ia tidak mempunyai kedudukan sebagai "penjabat umum". Sebaliknya seorang "Pegawai Catatan Sipil" (Ambtenaar van de Burgerlijke Stand) meskipun ia bukan ahli hukum, ia berhak membuat akta-akta otentik untuk hal-hal tertentu, umpamanya untuk membuat akta kelahiran, akta perkawinan, akta kematian. Demikian itu karena ia oleh Undang-undang ditetapkan sebagai "pejabat umum" dan diberi wewenang untuk membuat akta-akta itu.

\section{Tugas Notaris}

Sebagaimana diketahui Pasal 1 ayat (1) Undang-Undang Nomor 2 Tahun 2014 Tentang Perubahan Atas Undang-Undang Nomor 30 Tahun 2004 Tentang Jabatan Notaris telah menegaskan bahwa tugas pokok dari Notaris adalah membuat akta otentik dan akta otentik itu akan memberikan kepada pihak-pihak yang membuatnya suatu pembuktian yang mutlak. Hal ini dapat dilihat sebagaimana yang dinyatakan dalam Pasal 1870 KUHPerdata, bahwa:

"Suatu akta otentik memberikan di antara para pihak beserta ahli waris-ahli warisnya atau orang-orang yang mendapat hak dari pada mereka, suatu bukti yang sempurna tentang apa yang dimuat di dalamnya."

Menjalankan tugas jabatannya, Notaris tidak hanya berwenang untuk membuat akta otentik dalam arti menyusun, membacakan dan menandatangani dan dalam bentuk yang telah ditentukan oleh Undang-undang sebagaimana dimaksud oleh Pasal 1868 KUHPerdata, yang menyatakan bahwa:

"Suatu akta otentik ialah suatu akta yang di dalam bentuk yang ditentukan oleh Undangundang, dibuat oleh atau di hadapan pegawaipegawai umum yang berkuasa untuk itu di tempat dimana akta dibuatnya"

Tetapi kewenangan Notaris dalam membuat akta otentik dapat juga berdasarkan ketentuan yang terdapat dalam Pasal 15 ayat (1) Undang-Undang
Nomor 2 Tahun 2014 Tentang Perubahan Atas Undang-Undang Nomor 30 Tahun 2004 Tentang Jabatan Notaris yang berbunyi:

“ Notaris berwenang membuat Akta autentik mengenai semua perbuatan, perjanjian, dan penetapan yang diharuskan oleh peraturan perundang-undangan dan/atau yang dikehendaki oleh yang berkepentingan untuk dinyatakan dalam Akta autentik, menjamin kepastian tanggal pembuatan Akta, menyimpan Akta, memberikan grosse, salinan dan kutipan Akta, semuanya itu sepanjang pembuatan Akta itu tidak juga ditugaskan atau dikecualikan kepada pejabat lain atau orang lain yang ditetapkan oleh undang-undang “.

Dilihat dari uraian pasal tersebut di atas, dapat dikemukakan bahwa kewajiban terhadap Notaris untuk membuat suatu akta, kecuali apabila terdapat alasan-alasan yang mempunyai dasar untuk menolak pembuatan akta tersebut. Notaris dalam menjalankan tugas jabatannya juga dituntut harus memberikan nasehat hukum dan penjelasan mengenai ketentuan Undang-undang kepada pihakpihak yang bersangkutan.

Adanya hubungan erat antara ketentuan mengenai bentuk akta dan keharusan adanya pejabat yang mempunyai tugas untuk melaksanakannya, menyebabkan adanya kewajiban bagi pemerintah untuk menunjuk dan mengangkat Notaris.

Terhadap otentisitas suatu akta otentik yang dibuat di hadapan Notaris, dapat dilihat dari unsurunsur yang tercantum di dalam Pasal 1868 KUHPerdata tersebut di atas, yakni sebagai berikut:

"Suatu akta otentik ialah suatu akta yang didalam bentuk yang ditentukan oleh undang-undang, dibuat oleh atau di hadapan pegawai-pegawai umum yang berkuasa untuk itu ditempat dimana akta dibuatnya.'

Berkaitan dengan tugas dan wewenang Notaris yang diberikan oleh pemerintah kepadanya, untuk itu Notaris dalam menjalan tugas jabatannya harus berpegangan pada ketentuan-ketentuan yang telah ditetapkan oleh peraturan-peraturan yang ada, baik itu Undang-undang maupun Kode Etik Profesi Notaris. Notaris adalah merupakan suatu profesi, karena itu, terhadapnya perlu diberikan aturan etika profesi dalam bentuk kode etik, di samping diberikan kepadanya tempat bernaung dalam suatu organisasi profesi Notaris yang disebut dengan Ikatan Notaris Indonesia, atau yang disingkat dengan I.N.I .

Notaris dalam profesinya sesungguhnya adalah merupakan pejabat umum, yang dengan aktaaktanya akan menimbulkan alat-alat pembuktian 
tertulis dan mempunyai sifat otentik, sehingga dengan adanya peran Notaris akan mendorong masyarakat untuk mempergunakan alat-alat pembuktian tertulis (otentik). Oleh karena itu Notaris harus aktif dalam pekerjaannya dan bersedia melayani masyarakat manapun juga yang membutuhkan jasa-jasanya.

Negara merasa perlu menata kelembagaan notariat melalui sejumlah pembatasan-pembatasan, mengingat kewenangan lembaga Notariat diabdikan sepenuhnya untuk kepentingan yang lebih tinggi, yakni kepentingan masyarakat. Garis kewenangan formal yang diderivasi dari kekuasaan umum inilah yang membedakan jabatan Notaris dengan profesi-pofesi lainnya.

Berdasarkan hal di atas, pembatasan-pembatasan yang dimaksud dapat berupa peraturan yang mengikat di kalangan notaris yang diwujudkan dalam kode etik Notaris. Di dalam menjalankan tugas jabatannya, Notaris selain terikat dengan segala ketentuan yang tertuang dalam undangundang, juga harus ikut serta menegakkan ketertiban ditengah-tengah masyarakat.

Sehubungan dengan pelaksanaan tugas jabatannya, maka Notaris harus dikontrol dengan Kode Etik Profesi, bahwa organisasi profesi memiliki kepentingan untuk memperoleh jaminan agar anggotanya menjalankan tugasnya dengan memenuh standar etika profesi. Hal ini sangat penting, mengingat profesi hukum merupakan profesi mulia atau luhur, yang sangat berkaitan dengan kepentingan umum.

Selain diikat oleh kode etik Notaris, dalam menjalankan tugas dan kewenangannya ada 3 (tiga) aspek yang harus diperhatikan Notaris pada saat pembuatan akta. Aspek-aspek ini berkaitan dengan nilai pembuktian, yaitu:

\section{Lahiriah (uitwendige bewijskracht)}

Kemampuan lahiriah akta Notaris, merupakan kemampuan akta itu sendiri untuk membuktikan keabsahannya sebagai akta otentik (acta publica probant sese ipsa). Jika dilihat dari luar (lahirnya) sebagai akta otentik serta sesuai dengan aturan hukum yang sudah ditentukan mengenai syarat akta otentik, maka akta tersebut berlaku sebagai akta otentik, sampai terbukti sebaliknya, artinya sampai ada yang membuktikan bahwa akta tersebut bukan akta otentik secara lahiriah. Dalam hal ini beban pembuktian ada pada pihak yang menyangkal keotentikan akta Notaris. Parameter untuk menentukan akta Notaris sebagai akta otentik, yaitu tanda tangan dari Notaris yang bersangkutan, baik yang ada pada Minuta dan Salinan dan adanya awal akta (mulai dari judul) sampai akhir akta.

Nilai pembuktian akta Notaris dari aspek lahiriah, akta tersebut harus dilihat secara lahiriah tidak perlu dipertentangkan dengan alat bukti yang lainnya. Jika ada yang menilai bahwa suatu akta Notaris tidak memenuhi syarat sebagai akta, maka yang bersangkutan wajib membuktikan bahwa akta tersebut secara lahiriah bukan akta otentik.

Penyangkalan atau pengingkaran bahwa secara lahiriah akta Notaris sebagai akta otentik, bukan akta otentik, maka penilaian pembuktiannya harus didasarkan kepada syarat-syarat akta Notaris sebagai akta otentik. Pembuktian semacam ini harus dilakukan melalui upaya gugatan ke pengadilan. Penggugat harus dapat membuktikan bahwa secara lahiriah akta yang menjadi objek gugatan bukan akta Notaris.

\section{Formal (formele bewijskracht)}

Akta Notaris harus memberikan kepastian bahwa sesuatu kejadian dan fakta tersebut dalam akta betul-betul dilakukan oleh Notaris atau diterangkan oleh pihak-pihak yang menghadap pada saat yang tercantum dalam akta sesuai dengan prosedur yang sudah ditentukan dalam pembuatan akta Notaris.

Secara formal untuk membuktikan kebenaran dan kepastian tentang hari, tanggal, bulan, tahun, pukul (waktu) menghadap, dan para pihak yang menghadap, paraf dan tanda tangan para pihak/penghadap, saksi dan Notaris, serta membuktikan apa yang dilihat, disaksikan, didengar oleh Notaris (pada akta pejabat/berita acara), dan mencatatkan keterangan atau pernyataan para pihak/penghadap (pada akta pihak). Jika aspek formal dipermasalahkan oleh para pihak, maka harus dibuktikan dari formalitas dari akta, yaitu harus dapat membuktikan ketidakbenaran hari, tanggal, bulan, tahun, dan pukul menghadap, membuktikan ketidakbenaran mereka yang menghadap, membuktikan ketidakbenaran apa yang dilihat, disaksikan dan didengar oleh Notaris, juga harus dapat membuktikan ketidakbenaran pernyataan atau keterangan para pihak yang diberikan/disampaikan di hadapan Notaris dan ketidakbenaran tandatangan para pihak, saksi, dan Notaris ataupun ada prosedur pembuatan akta yang tidak dilakukan.

Dengan kata lain pihak yang mempermasalahkan akta tersebut harus melakukan pembuktian terbalik untuk menyangkal aspek formal dari akta Notaris. Jika tidak mampu membuktikan ketidakbenaran tersebut, maka akta tersebut harus diterima oleh siapa pun.

Tidak dilarang siapa pun untuk melakukan pengingkaran atau penyangkalan atas aspek formal akta Notaris, jika yang bersangkutan merasa dirugikan atas akta yang dibuat di hadapan Notaris atau yang dibuat oleh Notaris .

Pengingkaran atau penyangkalan tersebut harus dilakukan dengan suatu gugatan ke pengadilan umum, dan penggugat harus dapat membuktikan bahwa ada aspek formal yang 
dilanggar atau tidak sesuai dalam akta yang bersangkutan, misalnya bahwa yang bersangkutan tidak pernah merasa menghadap Notaris pada hari, tanggal, bulan, tahun, dan pukul yang tersebut dalam awal akta, atau merasa tanda tangan yang tersebut dalam akta bukan tanda tangan dirinya. Jika hal ini terjadi bersangkutan atau penghadap tersebut untuk menggugat Notaris, dan penguggat harus dapat membuktikan ketidakbenaran aspek formal tersebut .

\section{Materil (materielebewijskracht)}

Merupakan kepastian tentang materi suatu akta, bahwa apa yang tersebut dalam akta merupakan pembuktian yang sah terhadap pihak-pihak yang membuat akta atau mereka yang mendapat hak dan berlaku untuk umum, kecuali ada pembuktian sebaliknya (tegenbewijs). Keterangan atau pernyataan yang dituangkan/dimuat dalam akta pejabat (atau berita acara), atau keterangan atau para pihak yang diberikan/disampaikan di hadapan Notaris (akta pihak) dan para pihak harus dinilai benar berkata yang kemudian dituangkan/dimuat dalam akta berlaku sebagai yang benar atau setiap orang yang datang menghadap Notaris yang kemudian/keterangannya dituangkan/dimuat dalam akta harus dinilai telah benar berkata.

Jika ternyata pernyataan/keterangan para penghadap tersebut menjadi tidak benar berkata, maka hal tersebut tanggung jawab para pihak sendiri. Notaris terlepas dari hal semacam itu. Dengan demikian isi akta Notaris mempunyai kepastian sebagai yang sebenarnya, menjadi bukti yang sah untuk/di antara para pihak dan para ahli waris serta para penerima hak mereka. Jika akan membuktikan aspek materil dari akta, maka yang bersangkutan harus dapat membuktikan, bahwa Notaris tidak menerangkan atau menyatakan yang sebenarnya dalam akta (akta pejabat), atau para pihak yang lelah benar berkata (di hadapan Notaris) menjadi tidak benar berkata, dan harus dilakukan pembuktian terbalik untuk menyangkal aspek materil dari akta Notaris.

Ketiga aspek tersebut di atas merupakan kesempurnaan akta Notaris sebagai akta otentik dan siapa pun terikat oleh akta tersebut. Jika dapat dibuktikan dalam suatu persidangan pengadilan, bahwa ada salah satu aspek tersebut tidak benar, maka akta yang bersangkutan hanya mempunyai kekuatan pembuktian sebagai akta di bawah tangan atau akta tersebut didegradasikan kekuatan pembuktiannya sebagai akta yang mempunyai kekuatan pembuktian sebagai akta di bawah tangan.

Setiap pekerjaan dan jabatan tentu dibarengi dengan hal-hal yang menjadi tanggung jawabnya. Dalam menjalankan praktiknya seorang notaris memiliki kewajiban, kewenangan dan larangan atau pantangan. Kewajiban, kewenangan atau larangan merupakan inti dari praktik kenotaritan. Tanpa adanya ketiga elemen ini maka profesi dan jabatan notaris menjadi tidak berguna. Penting bagi masyarakat mengetahui kewajiban, kewenangan dan larangan bagi notaris agar mereka mengerti praktik kenotariatan sehingga tidak mudah tertipu oleh notaris, serta membantu negara dalam melakukan pengawasan terhadap para notaris.

\section{Kewajiban Notaris}

Notaris sebagai seorang pejabat umum yang diangkat oleh negara memiliki kewajiban yang diatur secara khusus dalam Undang-undang tentang jabatan notaris adapun kewajiban tersebut diatur dalam pasal 16 dan pasal 16 A Undang-Undang Nomor 2 Tahun 2014 Tentang Perubahan Atas Undang-Undang Nomor 30 Tahun 2004 Tentang Jabatan Notaris yang berbunyi :

“ (1) Dalam menjalankan jabatannya, Notaris wajib:a. bertindak amanah, jujur, saksama, mandiri, tidak berpihak, dan menjaga kepentingan pihak yang terkait dalam perbuatan hukum;b. membuat Akta dalam bentuk Minuta Akta dan menyimpannya sebagai bagian dari Protokol Notaris;c. melekatkan surat dan dokumen serta sidik jari penghadap pada Minuta Akta;d. mengeluarkan Grosse Akta, Salinan Akta, atau Kutipan Akta berdasarkan Minuta Akta;e. memberikan pelayanan sesuai dengan ketentuan dalam Undang-Undang ini, kecuali ada alasan untuk menolaknya;f. merahasiakan segala sesuatu mengenai Akta yang dibuatnya dan segala keterangan yang diperoleh guna pembuatan Akta sesuai dengan sumpah/janji jabatan, kecuali undang-undang menentukan lain;g. menjilid Akta yang dibuatnya dalam 1 (satu) bulan menjadi buku yang memuat tidak lebih dari 50 (lima puluh) Akta, dan jika jumlah Akta tidak dapat dimuat dalam satu buku, Akta tersebut dapat dijilid menjadi lebih dari satu buku, dan mencatat jumlah Minuta Akta, bulan, dan tahun pembuatannya pada sampul setiap buku;h. membuat daftar dari Akta protes terhadap tidak dibayar atau tidak diterimanya surat berharga; i. membuat daftar Akta yang berkenaan dengan wasiat menurut urutan waktu pembuatan Akta setiap bulan;j. mengirimkan daftar Akta sebagaimana dimaksud dalam huruf i atau daftar nihil yang berkenaan dengan wasiat ke pusat daftar wasiat pada kementerian yang menyelenggarakan urusan pemerintahan di bidang hukum dalam waktu 5 (lima) hari pada minggu pertama setiap bulan berikutnya;k. mencatat dalam repertorium tanggal pengiriman daftar wasiat pada setiap akhir bulan;

1. mempunyai cap atau stempel yang memuat lambang negara Republik Indonesia dan pada ruang 
yang melingkarinya dituliskan nama, jabatan, dan tempat kedudukan yang bersangkutan;m. membacakan Akta di hadapan penghadap dengan dihadiri oleh paling sedikit 2 (dua) orang saksi, atau 4 (empat) orang saksi khusus untuk pembuatan Akta wasiat di bawah tangan, dan ditandatangani pada saat itu juga oleh penghadap, saksi, dan Notaris; dann. menerima magang calon Notaris.(2) Kewajiban menyimpan Minuta Akta sebagaimana dimaksud pada ayat (1) huruf b tidak berlaku, dalam hal Notaris mengeluarkan Akta in originali.(3) Akta in originali sebagaimana dimaksud pada ayat (2) meliputi: a. Akta pembayaran uang sewa, bunga, dan pensiun;b. Akta penawaran pembayaran tunai;c. Akta protes terhadap tidak dibayarnya atau tidak diterimanya surat berharga;d. Akta kuasa;e. Akta keterangan kepemilikan; dan f. Akta lainnya sesuai dengan ketentuan peraturan perundang-undangan.(4) Akta in originali sebagaimana dimaksud pada ayat (2) dapat dibuat lebih dari 1 (satu) rangkap, ditandatangani pada waktu, bentuk, dan isi yang sama, dengan ketentuan pada setiap Akta tertulis kata-kata "BERLAKU SEBAGAI SATU DAN SATU BERLAKU UNTUK SEMUA".(5) Akta in originali yang berisi kuasa yang belum diisi nama penerima kuasa hanya dapat dibuat dalam 1 (satu) rangkap.(6) Bentuk dan ukuran cap atau stempel sebagaimana dimaksud pada ayat (1) huruf 1 ditetapkan dengan Peraturan Menteri. (7) Pembacaan Akta sebagaimana dimaksud pada ayat (1) huruf $m$ tidak wajib dilakukan, jika penghadap menghendaki agar Akta tidak dibacakan karena penghadap telah membaca sendiri, mengetahui, dan memahami isinya, dengan ketentuan bahwa hal tersebut dinyatakan dalam

penutup Akta serta pada setiap halaman Minuta Akta diparaf oleh penghadap, saksi, dan Notaris. (8) Ketentuan sebagaimana dimaksud pada ayat (7) dikecualikan terhadap pembacaan kepala Akta,

komparasi, penjelasan pokok Akta secara singkat dan jelas, serta penutup Akta.(9) Jika salah satu syarat sebagaimana dimaksud pada ayat (1) huruf $m$ dan ayat (7) tidak dipenuhi, Akta yang bersangkutan hanya mempunyai kekuatan pembuktian sebagai akta di bawah tangan.(10) Ketentuan sebagaimana dimaksud pada ayat (9) tidak berlaku untuk pembuatan Akta wasiat.(11) Notaris yang melanggar ketentuan sebagaimana dimaksud pada ayat (1) huruf a sampai dengan huruf 1 dapat dikenai sanksi berupa:a. peringatan tertulis; $b$ pemberhentian sementara;c. pemberhentian dengan hormat; atau

d. pemberhentian dengan tidak hormat.(12) Selain dikenai sanksi sebagaimana dimaksud pada ayat (11), pelanggaran terhadap ketentuan Pasal 16 ayat (1) huruf $\mathrm{j}$ dapat menjadi alasan bagi pihak yang menderita kerugian untuk menuntut penggantian biaya, ganti rugi, dan bunga kepada Notaris.(13)
Notaris yang melanggar ketentuan sebagaimana dimaksud pada ayat (1) huruf $\mathrm{n}$ dapat dikenai sanksi berupa peringatan tertulis."

Pasal 16A berbunyi sebagai berikut:

"Pasal 16A (1) Calon Notaris yang sedang melakukan magang wajib melaksanakan ketentuan sebagaimana dimaksud dalam Pasal 16 ayat (1) huruf a. (2) Selain kewajiban sebagaimana dimaksud pada ayat (1), calon Notaris juga wajib merahasiakan segala sesuatu mengenai Akta yang dibuatnya dan segala keterangan yang diperoleh guna pembuatan Akta."

Seorang notaris wajib bertindak jujur, seksama dan tidak memihak. Kejujuraran merupakan hal yang penting karena jika seorang notaris bertindak dengan ketidakjujuran maka akan banyak kejadian yang merugikan masyarakat. Bukan hanya itu, ketidakjujuran akan menurunkan tingkat kepercayaan masyarakat. Keseksamaan bertindak merupakan salah satu hal yang harus selalu dilakukan seorang notaris. Coba bayangkan jika seorang notaris bertindak ceroboh, tentu akan banyak yang dirugikan. Misalnya kesalahan penulisan nama, seharusnya "Monika" tetapi tertulis "Monik" maka efeknya akan besar bagi si pemilik akta. Jika sang pemilik akta mempunyai saudara yang bernama "Monik" maka dimata hukum orang yang terlibat dalam perjanjian adalah "Monik" bukan "Monika". Menjaga kerahasiaan terkait pembuatan akta juga harus dilakukan oleh seorang notaris.

Seorang notaris diharamkan untuk mengumbar kisah para klien tanpa ada persetujuan dari sang klien. Kerahasiaan ini juga merupakan amanat dari sumpah notaris. Mereka disumpah untuk dapat menjaga rahasia karena dengan menjaga rahasia para klien maka notaris juga sudah bertindak netral. Bayangkan, jika notaris tidak dapat menjaga rahasia berarti secara tidak langsung hal tersebut akan mempengaruhi para klien. Para klien akan merasa disudutkan atau diuntungkan dengan informasi notaris. Namun demikian, seorang notaris dapat "bernyanyi" tentang rahasia para klien jika diwajibkan oleh Undang-undang.

Notaris berkewajiban untuk membuat dokumen atau akta yang diminta masyarakat. Seorang notaris tidak dapat menolak permohonan tersebut karena memang itulah salah satu tugas pokok seorang notaris. Seorang notaris dapat dituntut jika menolak untuk membuat akta tanpa alasan yang jelas karena kewajiban membuat dokumen diamanatkan oleh Undang-undang. Jika terjadi penolakan berarti si notaris melanggar Undang-undang.

Jika seorang notaris memiliki alasan kuat untuk melakukan penolakan maka hal tersebut 
dapat dilakukan. Misalnya, seorang berkeinginan untuk melakukan sewa menyewa mobil, sedangkan pihak yang menyewakan mobil bukanlah pemilik yang sebenarnya dan tidak memiliki bukti pemberian kuasa dari pemilik sebenarnya.

Menghadapi kasus seperti ini, notaris dapat menolak pembuatan akta sewa menyewa. Penolakan didasari pada tidak jelasnya legalitas dari pihak yang mengajukan keinginan sewa menyewa.

Membuat daftar dari akta-akta yang sudah dikeluarkan dan menyimpan minuta akta dengan baik merupakan kewajiban lain dari seorang notaris. Minuta akta adalah asli akta notaris sebagaimana diatur dalam Pasal 1 Undang-Undang Nomor 2 Tahun 2014 Tentang Perubahan Atas Undang-Undang Nomor 30 Tahun 2004 Tentang Jabatan Notaris. Setelah minuta akta ditandatangani para pihak diatas materai dan telah sesuai dengan ketentuan, selanjutnya ditandatangani oleh saksisaksi dan terakhir oleh notaris. Setelah itu, notaris akan mengeluarkan salinan akta resmi untuk pegangan para pihak. Hal ini perlu dilakukan agar jika terjadi sesuatu terhadap akta yang dipegang kedua belah pihak maka notaris masih memiliki bukti perjanjian/penetapan. Hal ini juga perlu disadari oleh pihak pembuat akta karena banyak kejadian dimana akta yang dilakukan dengan menghilangkan atau merobek akta.

Seorang notaris wajib membacakan akta dihadapan pihak yang meminta pembuatan akta (klien) dan saksi-saksi. Setelah semua memahami dan menyetujui isi akta lalu diikuti dengan penandatanganan akta oleh semua yang hadir (notaris, para pihak, saksi-saksi). Pembacaan akta ini merupakan salah satu poin penting karena jika tidak dilakukan pembacaan maka akta yang Anda buat dapat dianggap sebagai akta dibawah tangan.

Seorang notaris magang wajib diterima disebuah kantor notaris. Notaris yang sudah berpraktik tidak boleh menolak permohonan magang yang diajukan oleh seorang notaris magang. Melalui program magang tersebut akan terjadi regenerasi di dunia kenotariatan karena salah satu syarat menjadi notaris adalah sudah melalui tahap magang selama dua tahun. Jika seorang notaris menolak kehadiran notaris magang dikantornya berarti secara tidak langsung dia "membunuh" eksistensi praktik kenotariatan. Notaris juga bertanggung jawab dalam pembuatan akta-akta yang memiliki kaitan dengan masalah pertanahan, tetapi keterlibatan notaris terbatas. Keterlibatan notaris diluar perbuatan peralihan hak atas tanah (jual beli tanah) dan perbuatan-perbuatan hukum atas tanah sebagaimana diatur dalam Pasal 2 Peraturan Pemerintah Nomor. 37 Tahun 1998 tentang Jabatan PPAT. Meskipun demikian jika notaris sudah diangkat menjadi PPAT maka ia berhak untuk mengurus pembuatan akta-akta seputar pertanahan secara lebih luas.

\section{Larangan Bagi Notaris}

Seorang notaris dalam menjalankan tugasnya dibatasi oleh koridor-koridor aturan. Pembatasan ini dilakukan agar seorang notaris tidak kebablasan dalam menjalankan praktiknya dan bertanggung jawab terhadap segala hal yang dilakukannya. Tetapi adanya pembatasan, seseorang cenderung akan bertindak sewenang-wenang. Demi sebuah pemerataan, pemerintah membatasi wilayah kerja seorang notaris. Sebagaimana Undang-Undang Nomor 2 Tahun 2014 Tentang Perubahan Atas Undang-Undang Nomor 30 Tahun 2004 Tentang Jabatan Notaris Pasal 17 mengatakan Notaris dilarang :

" menjalankan jabatan di luar wilayah jabatannya , meninggalkan wilayah jabatannya lebih dari 7 (tujuh) hari kerja berturut-turut tanpa alasan yang sah , merangkap sebagai pegawai negeri, merangkap jabatan sebagai pejabat negara, merangkap jabatan sebagai advokat , merangkap jabatan sebagai pemimpin atau pegawai badan usaha milik negara, badan usaha milik daerah atau badan usaha swasta , merangkap jabatan sebagai Pejabat Pembuat Akta Tanah dan/atau Pejabat Lelang Kelas II di luar tempat kedudukan Notaris, menjadi Notaris Pengganti; atau, melakukan pekerjaan lain yang bertentangan dengan norma agama, kesusilaan, atau kepatutan yang dapat mempengaruhi kehormatan dan martabat jabatan Notaris ".

\section{AKIBAT HUKUM TERHADAP PENANDATANGANAN AKTA NOTARIIL YANG DILAKUKAN TIDAK DIHADAPAN NOTARIS}

\section{Pengertian Akta dan Jenis Akta}

Akta adalah surat tanda bukti berisi pernyataan (keterangan, pengakuan, keputusan, dan sebagainya) tentang peristiwa hukum yang dibuat menurut peraturan yang berlaku, disaksikan, dibuat, dan disahkan oleh pejabat resmi .

Akta terdiri atas dua jenis, yaitu akta otentik dan akta dibawah tangan . Pengertian akta otentik menurut Pasal 1868 KUH Perdata yaitu :

"Suatu akta otentik ialah suatu akta yang di dalam bentuk yang ditentukan oleh undangundang dibuat oleh atau dihadapan pejabat umum yang berwenang untuk itu ditempat dimana akta itu dibuatnya".

Sedangkan menurut Undang-Undang Nomor 2 Tahun 2014 Tentang Perubahan Atas UndangUndang Nomor 30 Tahun 2004 Tentang Jabatan Notaris Pasal 1 Angka 7 yang berbunyi : 
“ Akta Notaris yang selanjutnya disebut Akta adalah akta autentik yang dibuat oleh atau di hadapan Notaris menurut bentuk dan tata cara yang ditetapkan dalam Undang-Undang ini “.

\section{Nilai Pembuktian Akta Notaris}

Berdasarkan penjelasan yang telah kami uraikan diatas akta Notaris sebagai akta otentik mempunyai kekuatan nilai pembuktian :

- Lahiriah

- Formal dan

- Materil

Dalam praktik pembuatan akta Notaris, ketiga aspek tersebut tidak dapat dipisahkan satu dengan lainnya. Namun aspek-aspek tersebut harus dilihat secara keseluruhan sebagai bentuk penilaian pembuktian atas keotentikan akta Notaris. Nilai pembuktian tersebut dapat dikaji dari beberapa putusan perkara pidana dan perkara perdata yang sesuai dengan ketiga aspek tersebut.

Perkara pidana dan perdata akta Notaris senantiasa dipermasalahkan dari aspek formal, terutama mengenai :

a. Kepastian hari, tanggal, bulan, tahun, dan pukul menghadap.

b. Pihak (siapa) yang menghadap Notaris.

c. Tanda tangan yang menghadap.

d. Salinan akta tidak sesuai dengan minuta akta.

e. Salinan akta ada, tanpa dibuat minuta akta.

f. Minuta akta tidak ditandatangani secara lengkap, tapi minuta akta dikeluarkan.

\section{Faktor-faktor Yang Menyebabkan Suatu Akta Menjadi Batal Demi Hukum}

Sebagaimana diatur dalam Pasal 1320 KUHPerdata bahwa suatu perjanjian harus memenuhi syarat sahnya perjanjian yaitu :

1. Adanya kata sepakat di antara dua pihak atau lebih;

2. Cakap dalam bertindak;

3. Adanya suatu hal tertentu;

4. Adanya suatu sebab yang halal.

Apabila perjanjian tersebut melanggar syarat objektif yaitu suatu hal tertentu dan suatu sebab yang halal maka perjanjian tersebut batal demi hukum. Sedangkan apabila perjanjian tersebut melanggar syarat subjektif yaitu kata sepakat dan cakap dalam bertindak maka perjanjian tersebut dapat dibatalkan.

Adapun faktor-faktor yang dapat menyebabkan suatu akta menjadi batal atau dapat dibatalkan adalah sebagai berikut :

1. Ketidakcakapan dan Ketidakwenangan Dalam Bertindak.

Secara umum dibedakan antara kewenangan bertindak dan kecakapan bertindak. Sejak seorang anak lahir, malahan anak dalam kandungan dianggap sebagai telah dilahirkan berkedudukan sebagai subjek hukum dan sebab itu pula memiliki kewenangan hukum . Kewenangan bertindak dari subjek hukum untuk melakukan tindakan hukum dapat dibatasi oleh atau melalui hukum. Setiap orang dianggap cakap melakukan tindakan hukum, tetapi kebebasan ini dibatasi pula oleh daya kerja hukum objektif.

Dikatakan mereka yang tidak mempunyai kecakapan bertindak atau tidak cakap adalah orang yang secara umum tidak dapat melakukan tindakan hukum. Bagi mereka yang di bawah umur batasan tertentu dikaitkan dengan ukuran kuantitas, yaitu usia. Sebagai penghadap untuk pembuatan akta Notaris harus memenuhi syarat paling sedikit berumur 18 tahun .

Mereka yang tidak mempunyai kewenangan bertindak atau tidak berwenang adalah orang yang tidak diperbolehkan untuk melakukan tindakan hukum tertentu. Notaris (termasuk para saksi) yang dengan perantaraannya telah dibuat akta wasiat dari pewaris tidak boleh menikmati sedikit pun dari apa yang pada mereka dengan wasiat itu telah dihibahkannya ,sebagaimana bunyi Pasal 907 KUHPerdata yaitu :

“ Notaris, yang mana dengan perantaranya telah dibuat akta umum dari sesuatu wasiat, dan segala saksi yang telah menyaksikan pembuatan akta itu, segala mereka tak diperbolehkan menikmati sedikitpun dari apa yang pada mereka dengan wasiat itu kiranya telah dihibahkannya"

Ini berarti bahwa Notaris tersebut boleh saja mendapat hibah wasiat dari orang lain asal bukan dari klien yang membuat wasiat di hadapannya tersebut.

2. Cacat Dalam Kehendak

KUHPerdata (Pasal 1322 - Pasal 1328

KUHPerdata) menetapkan secara limitatif adanya cacat kehendak, yakni kekhilafan/kesesatan (dwaling), penipuan (bedrog), dan paksaan (dwang).

a. Kekeliruan dan Penipuan

Dikatakan penipuan apabila seseorang dengan sengaja dengan kehendak dan pengetahuan memunculkan kesesatan pada orang lain. Penipuan dikatakan terjadi tidak saja bilamana suatu fakta tertentu dengan sengaja tidak diungkapkan atau disembunyikan, tetapi juga suatu informasi keliru dengan sengaja diberikan ataupun terjadi dengan tipu daya lain. Di dalam praktik penipuan dan kekhilafan menunjukkan perkaitan yang erat, tetapi ada pula sejumlah perbedaan.

b. Ancaman

Ancaman terjadi bilamana seseorang menggerakkan orang lain untuk melakukan suatu tindakan hukum, yakni dengan melawan hukum, mengancam, dan 
menimbulkan kerugian pada diri orang tersebut atau kebendaan miliknya atau terhadap pihak ketiga. Ancaman tersebut sedemikian menimbulkan ketakutan sehingga kehendak seseorang terbentuk secara cacat. Kehendak betul telah dinyatakan, tetapi kehendak tersebut muncul sebagai akibat adanya ancaman.

c. Penyalahgunaan Keadaan

Penyalahgunaan keadaan adalah keadaan tergeraknya seseorang karena suatu keadaan khusus untuk melakukan tindakan hukum dan pihak lawan menyalahgunakan hal ini. Keadaan khusus ini terjadi karena keadaan memaksa/darurat, keadaan kejiwaan tidak normal, atau kurang pengalaman.

3. Bertentangan dengan Undang-Undang

Berkenaan dengan perjanjian akan berkaitan dengan tiga aspek dari perbuatan hukum yang dimaksud, yakni :

a) Pelaksanaan dari tindakan hukum.

b) Substansi dari tindakan hukum.

c) Maksud dan tujuan tindakan hukum tersebut.

Suatu perjanjian yang dibuat pada saat tidak adanya larangan mengenai perbuatan hukum tersebut, tetapi ternyata di kemudian hari ada ketentuan undang-undang yang melarangnya, maka perjanjian tersebut tidak batal demi hukum, tetapi menjadi dapat dibatalkan atau mungkin masih dapat dilaksanakan setelah adanya izin tertentu. Penentuan apakah suatu perjanjian adalah batal demi hukum karena bertentangan dengan undangundang adalah pada waktu perjanjian tersebut dibuat.

4. Bertentangan dengan Ketertiban Umum dan Kesusilaan Baik

Pada umumnya perbuatan hukum dianggap bertentangan dengan ketertiban umum jika perbuatan tersebut melanggar atau bertentangan dengan asas-asas pokok (fundamental) dari tatanan masyarakat, sedangkan perbuatan hukum dianggap bertentangan dengan kesusilaan baik jika perbuatan tersebut melanggar atau bertentangan dengan norma kesusilaan dari suatu masyarakat.

\section{PENUTUP}

\section{Kesimpulan}

Berdasarkan data-data sebagaimana telah dikemukakan dan diuraikan diatas, maka dapat diperoleh kesimpulan sebagai berikut :

1) Notaris sebagai Pejabat Publik yang mempunyai kewenangan tertentu sebagaimana tersebut dalam Pasal 15 UUJN. Dengan kewenangan yang ada pada Notaris, maka akta Notaris mengikat para pihak atau penghadap yang tersebut di dalamnya atau siapa saja yang berkepentingan dengan akta tersebut. Jika dalam pembuatan akta Notaris tersebut :

1. berwenang untuk membuat akta sesuai dengan keinginan para pihak.

2. secara lahiriah, formal dan materil telah sesuai dengan aturan hukum tentang pembuatan akta Notaris, maka akta Notaris tersebut harus dianggap sah. Akta Notaris sebagai produk dari Pejabat Publik, maka penilaian terhadap akta Notaris harus dilakukan dengan Asas Praduga Sah (Vermoeden van Rechtmatigheid) atau Presumptio Iustae Causa. Asas ini dapat dipergunakan untuk menilai akta Notaris, yaitu akta Notaris harus dianggap sah sampai ada pihak yang menyatakan akta tersebut tidak sah. Untuk menyatakan atau menilai akta tersebut tidak sah harus dengan gugatan ke pengadilan umum. Selama dan sepanjang gugatan berjalan sampai dengan ada keputusan pengadilan yang mempunyai kekuatan hukum tetap, maka akta Notaris tetap sah dan mengikat para pihak atau siapa saja yang berkepentingan dengan akta tersebut.

Dalam gugatan untuk menyatakan akta Notaris tersebut tidak sah, maka harus dibuktikan ketidakabsahan dari aspek lahiriah, formal dan materil akta Notaris. Jika tidak dapat dibuktikan maka akta yang bersangkutan tetap sah mengikat para pihak atau siapa saja yang berkepentingan dengan akta tersebut.

2) Sebagaimana tertuang dalam Pasal - Pasal yang ada dalam Undang-Undang Jabatan Notaris menyebutkan : Dalam menjalankan jabatannya, Notaris berkewajiban membacakan akta di hadapan penghadap dengan dihadiri oleh paling sedikit 2 (dua) orang saksi dan ditandatangani pada saat itu juga oleh penghadap, saksi dan Notaris. Dalam arti penandatanganan akta di hadapan notaris, UUJN memberikan penjelasan bahwa arti dari kata di hadapan bahwa notaris harus hadir secara fisik dan menandatangani akta di hadapan penghadap dan saksi sebagaimana tertuang dalam . Jika notaris melanggar (tidak melakukan) ketentuan sebagaimana dimaksud dalam Pasal - Pasal tersebut, maka akta yang bersangkutan hanya mempunyai kekuatan pembuktian sebagai akta di bawah tangan.

Untuk menentukan akta Notaris yang mempunyai kekuatan pembuktian sebagai akta di bawah tangan atau akan menjadi batal demi hukum, dapat dilihat dan ditentukan dari : 
1. Isi (dalam) pasal-pasal tertentu yang menegaskan secara langsung jika Notaris melakukan pelanggaran, maka akta yang bersangkutan termasuk akta yang mempunyai kekuatan pembuktian sebagai akta di bawah tangan.

2. Jika tidak disebutkan dengan tegas dalam pasal yang bersangkutan sebagai akta yang mempunyai kekuatan pembuktian sebagian akta dibawah tangan, maka pasal lainnya yang dikategorikan melanggar, termasuk ke dalam akta batal demi hukum.

Akta yang mempunyai kekuatan bukti di bawah tangan ini tetap sah dan mengikat kecuali adanya putusan pengadilan yang telah mempunyai kekuatan hukum tetap yang menyatakan batalnya akta tersebut atau tidak mengikatkan akta tersebut.

\section{Saran-saran}

Dengan kesimpulan yang terurai seperti tersebut diatas, maka penulis akan mengemukakan saran, sebagai berikut :

1. Notaris diharapkan dalam menjalankan jabatannya selaku pejabat umum yang berwenang dalam pembuatan akta otentik, memahami dan melaksanakan ketentuanketentuan Peraturan Jabatan Notaris dan Undang-Undang Nomor 2 Tahun 2014 Tentang Perubahan Atas Undang-Undang Nomor 30 Tahun 2004 Tentang Jabatan Notaris sebagai pedoman dalam melaksanakan profesi Notaris.

2. Hendaknya Majelis Pengawas yang mengawasi Notaris dalam menjalankan tugas dan jabatannya adalah pengawas yang memiliki pengetahuan dan mengerti tentang kenotariatan khususnya dalam pembuatan akta otentik dan juga memiliki integritas moral yang tinggi.

3. Dengan adanya perlindungan hukum dilaksanakan terhadap Notaris, hendaknya bisa menjadi seorang pejabat umum yang profesional dalam jabatannya khususnya dalam pembuatan akta yang bersifat otentik dan melaksanakan tugas dan jabatannya benar-benar memperhatikan nilai luhur, martabat dan etika serta mematuhi peraturan perundang-undangan yang berlaku.

4. Agar supaya masyarakat dan aparat penegak hukum lebih mengetahui secara luas tentang apa itu Notaris , Kewajiban Notaris, Wewenang Notaris, Fungsi Notaris , Keabsahan akta-akta Notaris dan apa saja akibat hukumnya dari akta-akta tersebut jika dilanggar proses pembuatannya.

\section{DAFTAR PUSTAKA}

\section{LITERATUR}

Sudikno Mertokusumo, Hukum Acara Perdata Indonesia . Edisi Keempat, Yogyakarta : Liberty, Tahun 1993.

Johnny Ibrahim, Teori Metode Penelitian Hukum Normatif, Banyumedia Publishing, Malang Tahun 2006.

Peter Mahmud Marzuki. Penelitian Hukum. Universitas Airlangga. Surabaya. Tahun 2005.

H. Budi Untung, Visi Global Notaris, Andi, Yogyakarta, Tahun 2002 .

Kartini Soedjendro, Perjanjian Peraihan Hak atas Tanah yang Berpotensi Konflik,

Kanisius, Yogyakarta, , Jakarta, Tahun 2001

Habib Adjie, Sanksi Perdata dan Administratif Terhadap Notaris Sebagai Pejabat Publik, Refika aditama, Bandung, Tahun 2008.

Habib Adjie, Hukum Notaris Indonesia, Tafsir Tematik Terhadap UU No. 30 Tahun 2004 tentang Jabatan Notaris, Refika Aditama, Bandung, Tahun 2008 dan 2009.

Peter Mahmud Marzuki, Batas-Batas Kebebasan Berkontrak, Yudika, Fakultas Hukum Universitas Airlangga, Volume 18, Nomor 3, Tahun 2003

Philipus M. Hadjon, Formulir Pendaftaran Tanah Bukan Akta Otentik, Surabaya Post, 31 Tahun 2001 .

Tan Thong Kie, Studi Notariat, Serba Serbi Praktek Notaris, Ichtiar Baru Van Hoeve, Tahun 1994 .

\section{PERATURAN PERUNDANG-UNDANGAN:}

Kitab Undang-Undang Hukum Perdata (KUH Perdata)

Kitab Undang-Undang Hukum Pidana (KUHP)

Undang-Undang Nomor 2 Tahun 2014 Tentang Perubahan Atas Undang-Undang Nomor 30 Tahun 2004 Tentang Jabatan Notaris .

MAKALAH :

H. Bambang Eko Muljono .’Teknis Pembuatan Akta Tanah Serta Tugas dan Tanggung Jawab Pejabat Pembuat Akta Tanah " Tahun 2014 .

INTERNET :

Www.hukumonline.com 
Jurnal Independent Vol 2 No. 2 